8. Schleimer RP, MacGlashan DW, Peters SP, Naclerio R, If we take the regulation of the IgE production as Proud D, Adkinson NF, Lichtenstein LM $1984 \mathrm{~J}$ Allergy Clin Immunol 74: 473-481

9. Lewis RA, Austen KF $1984 \mathrm{~J} \mathrm{Clin}$ Invest 73: 889-897

10. Mencia-Huerta JM, Benhamou M 1986 In Kay AB (ed) Asthma, clinical pharmacology and therapeutic progress. Blackwell, Oxford pp 237-250

11. Rodger IW 1986 In Kay $A B$ (ed) Asthma, Clinical and pharmacology and therapeutic progress. Blackwell, Oxford, pp 114-127

12. Szentivanyi A $1968 \mathrm{~J}$ Allergy 42: 203-232

13. Vries $\mathrm{K}$ de, Gökemeyer JDM, Koëter GH, Monchy JGR de, Bork LE van, Kauffman HF, Meurs H 1982 In Morley J (ed) Bronchial hyperreactivity. Academic Press, London pp 107-121

14. Koëter GH, Meurs H, Kauffman HF, Vries K de 1982 Eur J Respir Dis 63 (suppl 121): 72-78

15. Meurs H, Koëter GH, Vries K de, Kauffman HF 1982 $\mathrm{J}$ Allergy $\mathrm{Clin}$ Immunol 70: 272-280

16. Meurs H, Kauffman HF, Timmermans A, Monchy JGR de, Koëter GH, Vries K de 1986 Int Archs Allergy Appl. Immunol., in press.

17. Meurs H, Kauffman HF, Timmermans A, Amsterdam FThM van, Koëter GH, Vries K de 1986 Biochem Pharmacol, in press.

PRODUCTION OF, AND INTERACTIONS BETWEEN, IMMUNOGLOBULINS

R.C. Aalberse, Central Laboratory of the Netherlands Red Cross Blood Transfusion Service and Laboratory for Experimental and Clinical Immunology, University of Amsterdam, Amsterdam

Immunoglobulins are the product of plasma cells. Plasma cells are derived from lymphocytes by a complex differentiation pathway that involves both antigen-independent and antigen-dependent stages. All the early differentiation steps are antigen-independent; this is understandable because the cells do not yet have the capability to recognize the antigen until a number of differentiation steps have taken place. Some of these differentiation steps require DNA rearrangements, notably the foining of a V(= variable region) gene to a $\mathrm{D}-$ (= diverisity region) gene and subsequently the joining of the VD gene to a $J$ (= joining region) gene and thus to the C(= constant region) gene. This DNA rearrangement generates a gene for a heavy chain of an IgM molecule. After another set of DNA rearrangements on a different chromosome an immunoglobuline light chain gene is generated. After this event the cell starts to synthesize surface-bound immunoglobulin, predominantly of the IgM type. This surface-bound immunoglobulin enables the cell to recognize a fitting antigen, so from now on the cell is immuno-competent. Interaction with such an antigen under suitable conditions results in cell proliferation and differentiation. During the cell divisions a further DNA rearrangement may take place: the isotype switch, or class-switch. In this DNA rearrangement the VDJ-gene on the heavy-chain chromosome is linked to another C-region gene, e.g. the $\mathrm{IgG}_{1}$ or the IgE-C region gene.

The differentiation leads to plasma cells committed to the production of one single type of immunoglobu$l i n$ and to the production of secondary (memory) $B$ cells which may respond upon a subsequent antigenic stimulation.

Factors governing the isotype regulation are largely unknown. Some regulation is evident in the isotype switch event; further isotype specific regulation occurs at the level of the isotype-committed B-cell. an example of isotype-specific regulation, it is clear that certain parasitic infections stimulate the production of IgE B-cells, presumably by stimulating isotype-switching to IgE; a further stimulus for the enhanced production of IgE are IgE-binding factors, produced by certain activated T-cells, which acts by stimulating IgE-bearing B-cells to differentiate into IgE-producing plasma cells.

In the response to environmental non-microbial glycoprotein antigens, three immunoglobulin isotypes are prominent: IgG $1, \mathrm{IgG}_{4}$ and IgE. IgE is prominent only in allergic individuals; IgG4 is prominent only after prolonged antigen exposure. The role of antibodies of the IgG4 isotype is still controversial; presumably IgG4 antibodies protect against the potential harmful effects of IgE- and IgG1 antibodies by preventing mast cell degranulation and complement activation.

\section{GENETIC DISEASE: PATIENTS; MOLECULES AND PREVENTION} H. Galjaard

Erasmus University, Head Dept. Clinical Genetics, University Hospital, Rotterdam

Congenital disorders become the major cause of infant mortality and morbidity in an increasing number of countries. The possibilities of primary prevention are very limited and the main emphasis has therefore been on newborn screening and early treatment, and on the early identification of couples at risk, genetic counseling and prenatal diagnosis followed by selective abortion. Enzyme replacement therapy has been attempted in patients with various types of lysosomal storage diseases and "gene therapy" is foreseen in patients with genetic disorders of the haemopoietic system. It seems, however, that in this area more basic research is needed about the exact nature of the molecular defect involved, the routing of gene products within the body, the efficiency of their uptake by various types of mutant cells and the corrective effect on cell metabolism of exogenous (enzyme) protein. Some of these aspects will be illustrated by experimental work on the genetic, molecular and cellular background of a number of lysosomal storage diseases.

At present the most effective approach towards prevention of handicaps is the early diagnosis of index patients with a chromosomal aberration, a genetic disease or other types of congenital anomalies followed by genetic counseling of relatives at increased risk. Various follow-up studies indicate that a high proportion of couples who are informed about an increased risk of affected offspring are deterred from a (next) pregnancy. For those who still want to reproduce, there is the option of chorion analysis, amniotic fluid (cell) analysis or ultrasonography in each pregnancy. The scope of prenatal diagnosis will be further widened by the possibilities of demonstrating gene mutations or polymorphisms closely linked to disease using recombinant DNA technology. Also for genetic diseases with a relatively high incidence, carrier screening programmes will enable couples to prevent the birth of a first affected baby in their family. In the future, the technology will also allow the prediction of diseases or of increased susceptibility to environmental factors. Such developments require timely attention to psychological, social and educational aspects. Such factors also play a major role in the participation of presently available technology as will be illustrated by 
studies on psychosocial aspects of prenatal diagnosis.

\section{DEFECTIVE PROCESSING OF LYSOSOMAL ENZYMES}

Kurt von Figura, Andrej Hasilik, Regina Pohlmann, Peter Lemansky and Thomas Braulke

Physiologisch-Chemisches Institut, University of Münster, D-4400 Münster, FRG

Lysosomal enzymes are synthesized at the rough endoplasmic reticulum as glycosylatedprecursors of high molecular weight. In the endoplasmic reticulum and following in the Golgi complex they undergo a series of modifications that involve cleavage of the aminoterminal signal peptide, disulfide binding, oligosaccharide processing and subunit association. Mannose 6-phosphate residues added in the Golgi complex serve as a signal for recognition by mannose 6-phosphate specific receptors. The receptorligand complexes are routed to a prelysosomal acidic compartment, where the lysosomal enzymes and receptors dissociate. The receptors return to the site, where they bind lysosomal enzymes (within or distal to the trans-Golgi). A second mannose 6-phosphate receptor dependent pathway ensures receptor-mediated endocytosis of (exogenous) lysosomal enzymes. The pathways for receptor-mediated transport of endogenous and exogenous lysosomal enzymes are connected and both involve clathrin-coated vesicles. The lysosomal enzymes released from the receptors are transported to lysosomes, where they undergo a limited proteolysis, termed maturation. It has become apparent that defective activity of a lysosomal enzyme in a lysosomal storage disease can be caused by one of the following reasons: 1 . Defective synthesis of the lysosomal enzyme polypeptide. 2. Defective transport of the newly synthesized lysosomal enzyme to lysosomes. 3. Instability of the lysosomal enzyme polypeptide within the lysosomes. 4. Deficiency in a cofactor required for activation of the lysosomal enzyme or for presenting the substrate. 5. Synthesis of a catalytically inactive lysosomal enzyme polypeptide. A single mutation may affect several of these parameters, e.g. catalytic activity and stability or transport properties and stability. The lysosomal storage disorders in which different mutations have been identified by studying the biosynthesis and processing of lysosomal enzymes comprise the following disorders: M. Tay-Sachs $(1,2)$, Pompe $(3,4)$, fucosidosis $(5)$, metachromatic leukodystrophy (6), Gaucher (7), Fabry (8) and Maroteaux-Lamy (9). The analysis of the molecular defects in lysosomal storage disorders using the recently cloned cDNAs for lysosomal enzymes will provide an increased understanding of the requirements for synthesis, processing, stability and transport of lysosomal enzymes under normal conditions.

\section{References:}

1. Proia RL and Neufeld EF 1982 Proc Natl Acad Sci U.S.A. 79: 6360

2. d'Azzo A, Proia RL, Kolodny EH, Kaback MM and Neufeld EF $1984 \mathrm{~J}$ Biol Chem 259: 11070

3. Steckel F, Gieselmann V, Waheed A, Hasilik A, von Figura K, Elferink RO, Kalsbeek $R$ and Tager JM 1982 FEBS Lett 150: 69

4. Reuser AJJ, Kroos M, Oude Elferink RPJ and Tager JM 1985 J Biol Chem 260: 8336

5. Johnson $K$ and Dawson G 1985 Biochem Biophys Res Commun 133: 90

6. von Figura K, Steckel $F$ and Hasilik A 1983 Proc Natl Acad Sci U.S.A. 80: 6066
7. Ginns EI, Brady RO, Pirruccello S, Moore C, Sorrell $\mathrm{S}$, Furbish FS, Murray GJ, Tager $\mathrm{J}$ and Barranger JA 1982 Proc Natl Acad Sci U.S.A. 79: 5607

8. Lemansky P, Bishop DF, Desnick RJ, Hasilik A and von Figura K $1986 \mathrm{~J}$ Biol Chem submitted

9. Conary J, Beck M, Hasilik $A$ and von Figura $K$ (unpublished)

BONE MARROW TRANSPLANTATION FOR THE TREATMENT OF LYSOSOMAL STORAGE DISEASES

Kenneth Hugh-Jones

Westminster Childrens Hospital, London, Great-Britain

Replacement treatment by the use of pure enzymes in various lysosomal storage diseases (LSD) has as yet not produced permanent clinical improvement. Brady et al have attempted this in both Gaucher's disease (1) and Niemann-Pick Disease (2) using enzyme made from human placenta. Neither has implantation of fibroblasts (3) or amnion-epithelial cells (4) given any beneficial effects.

In this paper evidence will be produced to show that a successful bone marrow transplantation (BMT) can produce an everlasting source of enzyme. When the missing enzyme can be demonstrated in the white cells, and that this treatment can be clinically effective.

In Wolman's Disease a satisfactory graft resulted in an adequate level of acid esterase and acid lipase both in the white cells and in liver biopsy along with mobilisation and disappearance of cholesterol from the liver (5).

In GM gangliosidosis a stable white cell engraftment led to the disappearance of the hepatosplenomegaly but there was no improvement in the neurological regression, so that the patient died fourteen months after the graft, thus not altering the natural history of the disease (6).

In Niemann-Pick Disease type B (non-neurological) a successful graft has led to some diminution in the stored sphingomyelin within 80 days of BMT. Hopefully the adequate engraftment of normal marrow will continue to produce a normal white cell level of the missing enzyme, sphingomyelinase, which will lead to the disappearance of the hepatosplenomegaly in time, as has occurred in all other cases of LSD so far transplanted.

Five cases of Gaucher's Disease have been successfully engrafted with complete resolution of the hepatosplenomegaly, clearing of the lung infiltrate and slow improvement in the radiological appearances of the bones, clinically a very satisfactory result (7).

The results in the mucopolysaccharidoses (MPS) seem to very in the different types. In all the hepatosplenomegaly resolved, if there is corneal clouding this improves, there is improvement in the cardiac signs if there is evidence of cardiac involvement. Similarly joint mobility improves but there have been very differing results so far as the CNS involvement is concerned.

Six consecutive cases of Hurler's Disease (MPS I) have all shown that the expected regression in intellectual performance has not occurred, three to six years (average 4.6 years) after the graft and three children are already in normal schools. But the evaluable cases of Hunter's Disease (MPS II) continue to regress. Similarly twins transplanted for San fillipo-B Disease (MPS IIIB) are not deteriorating nearly five years after grafting, but one child with San fillipo-A (MPS IIIA) is. (8). Although all these 